\title{
EFEKTIVITAS INFORMASI KARIR DENGAN MEDIA BUKU BERGAMBAR UNTUK MENINGKATKAN PEMAHAMAN STUDI LANJUTAN SISWA
}

\author{
Nurhidayatullah Dahlan \\ Bimbingan Konseling, Universitas Negeri Makassar \\ Email : nurhidaya_tullah@ymail.com
}

\begin{abstract}
The study aims at discovering (1) the description of understanding the advanced study of students at SMPN 23 Makassar before and after the service given in a form of career information service using picture book media, (2) the effectiveness of career information service using picture book media to develop understanding on advanced study of students at SMPN 23 Makassar. The study employed experiment approach (True Experimental Design) in a form of pretest-posttest Control Group Design. Data were collected using questionnaire and observation. Data were analyzed by employing statistic descriptive non parametric wilcoxon signed ranks test. The result of the study indicate that (1) the description of understanding advanced study of students at SMPN 23 Makassar before career information service using picture book media was given, is in low category and after the service was given, it develops, which is in high category, (2) the career information service using picture book media is effective to develop understanding of advanced study of students at SMPN 23 Makassar.
\end{abstract}

Keywords : Career Information, Advanced Study of Students

\begin{abstract}
Abstrak: Tujuan penelitian ini adalah (1) Untuk megetahui gambaran pemahaman terhadap studi lanjutan siswa SMP negeri 23 Makassar sebelum dan sesudah diberikan perlakuan berupa layanan informasi karir dengan media buku bergambar (2) Untuk mengetahui efektifitas layanan informasi karir dengan media buku bergambar untuk meningkatkan pemahaman terhadap studi lanjutan siswa di SMP Negeri 23 Makassar. Penelitian ini menggunakan pendekatan eksperimen (True Experimental Designs) dalam bentuk Pretest-Posttest Control Group Design. Penelitian ini menggunakan teknik pengumpulan data melalui angket, dan observasi. Analisis data menggunakan analisis statistic deskriptif non parametric wilcoxon signed ranks test. Hasil penelitian ini menunjukkan (1) Gambaran pemahaman terhadap studi lanjutan siswa di SMP Negeri 23 Makassar sebelum diberi layanan informasi karir dengan media buku bergambar berada pada kategori rendah, setelah diberi layanan informasi karir dengan media buku bergambar mengalami peningkatan berada pada kategori tinggi (2) Layanan informasi karir dengan media buku bergambar efektif dapat meningkatkan pemahaman terhadap studi lanjutan siswa di SMP Negeri 23 Makassar.
\end{abstract}

Kata Kunci: Informasi Karir, Studi Lanjutan 


\section{PENDAHULUAN}

Pada umumnya manusia memerlukan suatu pekerjaan, dimana dengan pekerjaan yang digelutinya tersebut membawanya pada tujuan yang diinginkan. Di dalam masyarakat secara luas terdapat berbagai jenis pekerjaan, tetapi pekerjaan yang telah digelutinya tidak semuanya memperoleh hasil serta membahagiakan sebagaimana yang menjadi tujuan hidupnya.

Upaya yang ditempu untuk mengatasi hal tersebut antara lain seperti yang dikemukakan oleh Hoppock (Gani, 2012) bahwa informasi mengenai diri sendiri berpengaruh terhadap pemilihan jabatan karena informasi itu membantu kita di dalam antisipasi, apakah kita akan berhasil atau tidak dalam melaksanakan pekerjaan yang di tawarkan.

Selanjutnya, Sering dijumpai adanya kebingungan, keragu-raguan dan kesulitan diantara para siswa yang sedang menekuni studinya di Pendidikan formal dan akan mempersiapkan dirinya untuk meniti karir di masa-masa mendatang, terutama karena diantara para siswa kurang memahami dirinya, memahami dunia kerja, ambisinya dalam dunia kerja dan peningkatan karirnya.

Dalam rangka berupaya membantu para siswa di sekolah memahami dunia kerja, karir, dan lingkungannya maka dipandang perlu memberikan informasi tentang jenis-jenis karir, pekerjaan atau jabatan yang tersedia dalam pasaran kerja baik dalam skala lokal maupun nasional sehingga dapat menambah pemahaman karir siswa.

Sejalan dengan permasalahan di atas, maka dengan diadakannya penetapan program pilihan untuk membantu siswa mengarahkan diri pada suatu bentuk pilihan studi lanjutan yang matang dan tepat sesuai kemampuan yang dimilikinya sehingga peserta didik dapat mengaktualisasikan diri secara optimal.

Peserta didik SMP pada umumnya berusia 13-15 tahun, atau secara psikologi berada pada masa remaja awal. Menurut (Yusuf, 2008) menyatakan masa remaja merupakan proses terbentuknya pendirian atau pandangan hidup atau cita-cita hidup yang dapat dipandang sebagai penemuan nilai-nilai kehidupan.

Nursalim (2002: 22) Layanan informasi adalah "kegiatan bimbingan yang bermaksud membantu siswa untuk mengenal lingkungannya, yang sekiranya dapat dimanfaatkan untuk masa kini maupun masa yang akan datang".

Menurut Prayitno (2004: 259) menjelaskan bahwa Layanan informasi adalah layanan bimbingan konseling yang memungkinkan peserta didik (klien) menerima dan memahami berbagai informasi (seperti informasi pendidikan dan informasi jabatan) yang dapat digunakan sebagai bahan pertimbangan dan pengambilan.

Menentukan studi lanjut bukanlah hal yang mudah dan tidak asal pilih saja, karena jika salah dalam memilih akan berakibat fatal, untuk itu perlu sekali pembekalan sejak dini mengenai informasi mengenai studi lanjut. Sutikna (1998: 17) mengartikan studi lanjut sebagai "pendidikan sambungan atau lanjutan setelah tamat dari pendidikan yang saat ini ditempuh". Studi lanjut yang dimaksud dalam hal ini adalah pendidikan lanjutan setelah menamatkan SMP dan ingin melanjutkan ke jenjang berikutnya.

Pemberian layanan informasi studi lanjut menggunakan media buku bergambarini diharapkan siswa lebih bersemangat dan tertarik untuk memahami informasi studi lanjut. Informasi studi lanjut ini berupa macam-macam studi lanjut seperti informasi tentang berbagai jurusan apa yang ada di SMA atau SMK dan setelah lulus SMA atau SMK bisa lanjut kemana.

Kenyataan dilapangan menunjukkan bahwa tingkat pemahaman terhadap studi lanjut siswa di SMP Negeri 23 Makassar, khususnya pada kelas VIII (Delapan) masih rendah, hal ini terkait dari beberapa pihak yaitu koordinator BK dan siswa itu sendiri. Adapun wawancara dari koordinator BK mengatakan bahwa terdapat beberapa siswa kelas VIII yang teridentifikasi memiliki pemahaman terhadap studi lanjut yang rendah dan mengakibatkan kesulitan untuk memilih studi lanjut pada jenjang sekolah selanjutnya setelah lulus dari sekolah menengah pertama. Beliau menambahakan bahwa salah satu upaya yang telah dilakukan guru BK untuk meningkatkan pemahaman studi lanjut siswa adalah melaksanakan layanan informasi melalui metode ceramah klasikal, namun hasil yang diperoleh belum cukup baik karena siswa merasa perlu adanya penambahan materi yang lengkap tentang studi lanjut. Selanjutnya yang didukung oleh hasil observasi lapangan menunjukkan bahwa terdapat beberapa siswa belum tahu pasti atau belum bisa menentukkan 
arahnya studi lanjutan setelah tamat di SMP nantinya.

Siswa yang kurang pemahaman studi lanjut ditandai dengan adanya 1 . Tidak mengenal potensi diri (bakat dan minat), dimana siswa harus mengenal bakat minat siswa karena tidak akan pernah berkembang seseorang apabila mereka tidak memiliki minat akan suatu pekerjaan, sama halnya dengan pemilihan studi lanjut, apabila siswa sudah tidak berminat dengan sekolah atau jurusan itu maka itu akan membuat siswa akan kurang nyaman dengan jurusan. 2. Tidak mampu memahami sekolah lanjutan, banyak siswa yang masih kurang pemahaman di sekolah lanjutan yang akan dipilihnya setelah tamat SMP nantinya hanya memahami dari sisi luarnya saja tidak terlalu mendalam. 3. Kurang dapat membedakan sekolah lanjutan, siswa juga masih kurang dapat membedakan sekolah lanjutan yang akan nanti dia pilih. 4. Tidak mampu membuat keputusan, sebagian siswa belum bisa membuat keputusan sendiri karena adanya rasa ragu-ragu dalam diri siswa, sebagian siswa dalam pemilihan sekolah lanjutan karena kemauan orang tua, atau karena factor teman sebaya.

Banyak siswa yang mengalami kekurangan informasi tentang studi lanjut terutama yang berkaitan dengan Sekolah Menengah Pertama (SMP) sehingga cenderung menjadi salah satu hambatan dalam menentukan arah pilih studi lanjut. Hal ini salah satunya disebabkan oleh kurang intensifnya pelaksanaan layanan informasi di sekolah. Tujuan dari penelitian ini adalah: Untuk megetahui gambaran pemahaman terhadap studi lanjutan siswa SMP negeri 23 Makassar sebelum dan sesudah diberikan perlakuan berupa layanan informasi karir dengan media buku bergambar, Untuk menguji ada tidaknya pengaruh Layanan informasi karir dengan media buku terhadap peningkatkan pemahaman studi lanjutan siswa di SMP Negeri 23 Makassar.

\section{METODE}

Penelitian ini merupakan jenis penelitian kuantitatif yang menguji secara langsung pengaruh suatu variabel yang lain dan menguji hipotesis tentang perbedaan tingkat pemahaman terhadap studi lanjut siswa antara kelompok kontrol dan kelompok eksperimen sebelum dan sesudah diberikan perlakuan layanan informasi karir dengan media buku bergambar. Adapun disain ekperimen yang digunakan dalam penelitian ini adalah True Experimental Designs dalam bentuk Pretest-Posttest Control Group Design yang akan mengkaji tentang efektifitas layanan informasi karir dengan media buku bergambar untuk meningkatkan pemahaman terhadap studi lanjutan siswa.

Adapun Disain eksperimen yang digunakan adalah Pretest-Posttest Control Group Design yang dapat digambarkan sebagai berikut:
Kelompok
Pre test
Treament
Post Test

$\begin{array}{llll}\text { Eksperimen (E) } & \mathrm{O}_{1} & \mathrm{X} & \mathrm{O}_{3}\end{array}$

$\begin{array}{lll}\text { Kontrol (K) } & \mathrm{O}_{2} & \mathrm{O}_{4}\end{array}$

Gambar 3.1 Pendekatan dan Disain Penelitian (Wiersma, 1995: 117-120)

$\mathrm{O}_{1}$ dan $\mathrm{O}_{2} \quad$ : Tingkat Pemahaman terhadap studi lanjut siswa pada Pretest

$\mathrm{O}_{3}$ dan $\mathrm{O}_{4} \quad$ : Tingkat Pemahaman terhadap studi lanjut siswa pada Posttest

$\mathrm{O}_{3} \quad$ : Tingkat Pemahaman terhadap studi lanjut siswa setelah diberikan perlakuan layanan informasi karir dengan media buku bergambar.
$\mathrm{O}_{4} \quad$ : Tingkat Pemahaman terhadap studi lanjut yang tidak diberikan perlakuan layanan informasi karir dengan media buku bergambar tetapi dengan metode yang lain (ceramah) yang di sampaikan oleh guru pembimbing dari sekolah tersebut.
$\mathrm{O}_{1}$ dan $\mathrm{O}_{3}$
:Kelompok Eksperimen
$\mathrm{O}_{2}$ dan $\mathrm{O}_{4}$
: Kelompok Kontrol 
$\mathrm{X}$

\author{
: Perlakuan diberikan sebanyak \\ 5 (lima kali).
}

Untuk menentukan besarnya populasi dalam penelitian ini terlebih dahulu peneliti melakukan wawancara guna mendapatkan informasi mengenai siswa yang teridentifikasi mengalami kurang dalam pemahaman studi lanjutan. Berdasarkan hasil wawancara langsung dari guru BK yang dilaksanakan pada tanggal 4 s.d 6 Pebruari 2014. Hasil wawancara tersebut diperoleh data seperti, siswa belum mengenal potensi dirinya, kurang memahami sekolah lanjutan, dan tidak mengetahui arah pilihannya, serta tidak mampu membuat keputusan setelah tamat SMP.

Teknik pengambilan sampel (teknik sampling) yang digunakan adalah multistage random sampling. Teknik pengambilan sampel dilakukan melalui 3 tahap. Teknik disebut multistage random sampling.

Teknik Pengumpulan Data yang digunakan yaitu Angket. merupakan teknik pengumpulan data yang dilakukan dengan cara memberi seperangkat pernyataan tertulis kepada respon untuk dijawabnya. Angket ini diberikan kepada kelompok eksperimen dan kelompok kontrol untuk memperoleh gambaran tentang pemahaman terhadap studi lanjutan siswa pada kelompok eksperimen sebelum (pre-test) maupun sesudah (post-test) diberikan pemahaman terhadap studi lanjutan siswa dengan menggunakan layanan informasi karir dengan media buku bergambar.

Observasi.Teknik observasi ini dilakukan untuk mengetahui keseriusan siswa dalam mengikuti kegiatan pemberian media buku bergambar pada kelompok eksperimen dalam pemahaman terhadap studi lanjutan siswa. Riduwan (2009: 76) mengemukakan bahwa observasi yaitu melakukan pengamatan secara langsung ke objek penelitian untuk melihat dari dekat. Adapun aspek-aspek yang diobservasi adalah umum, pemahaman siswa terhadap studi lanjut, dan inisiatif selama kegiatan. Cara memberi tanda cek $(\sqrt{ })$ pada setiap aspek yang muncul. Agar data aktivitas siswa dapat diperoleh dengan akurat maka peneliti dibantu oleh salah satu seorang guru bimbingan konseling.

Ada dua jenis instrumen yang yang merupakan bahan perlakuan dalam penelitian ini yaitu:

1. Bahan perlakuan berupa skenario.

Berupa pemberian informasi karir dengan media buku bergambar, kegiatan ini terbagi dalam sesi pertemuan termasuk pretest dan posttest.

2. Instrumen pengumpulan data

Instrumen pengumpulan data, media buku bergambar dan angket yang terlebih dahulu divalidasi ahli dan selanjutnya diuji lapangan terbatas untuk mengetahui validasi dan realibilitasnya.

Teknik analisis data yang digunakan adalah Analisis statistik deskriptif, dimaksudkan untuk pemahaman terhadap studi lanjutan siswa di SMP Negeri 23 Makassar sebelum dan sesudah perlakuan berupa pemberian informasi karir dengan media buku bergambar.

Analisis statistik inferensial dimaksudkan untuk menguji kebenaran hipotesis penelitian. Analisis dilakukan untuk mengetahui apakah ada pengaruh efektifitas layanan informasi karir terhadap pemahaman studi lanjutan siswa di SMP Negeri 23 Makassar, dengan menggunakan uji wilcoxonnon parametric kemudian dianalisis dengan menggunakan SPSS 20,0.

\section{HASIL DAN PEMBAHASAN}

\section{Hasil}

Analisis statistik deskriptif dilakukan untuk memperoleh gambaran tingkat pemahaman terhadap studi lanjutan siswa sebelum dan sesudah diberikan layanan informasi karir dengan media buku bergambar terhadap siswa kelas VIII di SMP Negeri 23 Makassar. Data hasil penelitian yang diperoleh adalah data hasil pengisian angket pemahaman terhadap studi lanjutan. 
Tabel 4.1 Perbandingan Hasil Pelaksanaan Pre-test dan Post-test kelompok eksperimen

\begin{tabular}{cccccc}
\hline Interval & Kategori & \multicolumn{4}{c}{ Kelompok Eksperimen } \\
& & \multicolumn{2}{c}{ Pre-test } & Post-test & \\
& & $f$ & $(\%)$ & $f$ & $(\%)$ \\
\hline \multirow{2}{*}{$151-185$} & Sangat Tinggi & - & - & 4 & $20 \%$ \\
\hline $116-150$ & Tinggi & - & - & 16 & 80 \\
\hline $81-115$ & Rendah & 14 & $70 \%$ & - & - \\
\hline $46-80$ & Sangat Rendah & 6 & $30 \%$ & - & - \\
\hline & & 20 & $100 \%$ & 20 & $100 \%$ \\
\hline
\end{tabular}

Tabel 4.3 Perbandingan Hasil Pelaksanaan Pretest dan Posttest kelompok kontrol

Kelompok Kontrol

\begin{tabular}{cccccc}
\multirow{2}{*}{ Interval } & \multirow{2}{*}{ Kategori } & \multicolumn{2}{c}{ Pre-test } & \multicolumn{2}{c}{ Post-test } \\
\cline { 3 - 6 } & & $\boldsymbol{f}$ & $\mathbf{( \% )}$ & $\boldsymbol{f}$ & $\mathbf{( \% )}$ \\
\cline { 3 - 6 } & & - & - & - & - \\
\hline $151-185$ & Sangat Tinggi & - & - & - & - \\
\hline $116-150$ & Tinggi & 15 & $75 \%$ & 18 & $90 \%$ \\
\hline $81-115$ & Rendah & 5 & $25 \%$ & 2 & $10 \%$ \\
\hline $46-80$ & Sangat Rendah & 20 & $100 \%$ & 20 & $100 \%$ \\
\hline Jumlah & & & & &
\end{tabular}

Sumber : Hasil analisis item kelompok kontrol

Observasi. Kemudian dari hasil observasi selama kegiatan pemberian layanan informasi karir dengan media buku bergambar yang dilaksanakan dalam lima tahap, untuk lebih jelasnya dapat dilihat pada tabel di atas, menunjukkan persentase siswa dalam memenuhi setiap item observasi selama pemberian perlakuan. Terdapat tiga kolom utama yaitu persentase, kriteria dan pertemuan. Pada kolom pertemuan terdapat lima sesi pemberian perlakuan yang dituliskan dalam angka romawi.

Untuk mengetahui layanan informasi karir dengan media buku maka diuji dengan uji wilcoxon dengan membandingkan perbedaan hasil pre-test dan post-test hasil skala pemahaman terhadap studi lanjutan siswa. Proses analisis data penelitian ini menggunakan bantuan program SPSS 20,0 dengan uji statistik wilcoxon. Pengambilan keputusan adalah jika probabilitas $>0,05$, maka $\mathrm{H}_{0}$ diterima, jika probabilitas $<0,05$, maka $\mathrm{H}_{0}$ ditolak. Proses pelaksanaan layanan informasi karir dengan media buku bergambar tersebut di atas, maka dapat dikatakan bahwa pada proses pemberian layanan informasi karir dengan media buku bergambar dapat meningkatkan pemahaman terhadap studi lanjutan siswa. Selain itu dari proses tersebut dapat dikatakan bahwa siswa sangat membutuhkan berbagai materi yang berkaitan dengan materi yang berkaitan dengan pemahaman terhadap studi lanjutan siswa setelah tamat SMP nantinya.

Jadi, setiap pelaksanaan layanan informasi karir dengan media buku bergambar ini, peneliti dibantu oleh guru pembimbing untuk mengobservasi setiap pertemuan yang dilakukan lalu mencatat atau member tanda ceklist $(\sqrt{ })$ pada pedoman observasi aspek-aspek yang muncul pada setiap siswa yang melakukan layanan informasi dengan media buku bergambar. Setiap selesai latihan, peneliti melakukan tanya jawab/diskusi dengan siswa.

Tingginya pemahaman terhadap studi lanjutan siswa di SMP Negeri 23 Makassar disebabkan pemberian informasi tentang berbagai jurusan apa yang ada di SMA/MAN atau SMK dan setelah lulus SMA/MAN atau SMK bisa lanjut kemana dalam bentuk media buku bergambar. Siswa di sekolah memahami dunia kerja, karir, dan lingkungannya maka dipandang perlu memberikan informasi tentang jenis-jenis karir, pekerjaan atau jabatan yang tersedia dalam pasaran kerja baik dalam skala lokal maupun nasional sehingga dapat menambah pemahaman karir siswa. 
Berdasarkan uraian proses pelaksanaan layanan informasi karir dengan media buku bergambar tersebut di atas, maka dapat dikatakan bahwa pada proses pemberian layanan informasi karir dengan media buku bergambar dapat meningkatkan pemahaman terhadap studi lanjutan siswa. Selain itu dari proses tersebut dapat dikatakan bahwa siswa sangat membutuhkan berbagai materi yang berkaitan dengan materi yang berkaitan dengan pemahaman terhadap studi lanjutan siswa setelah tamap SMP nantinya.

Berdasarkan hasil analisis observasi pada pertemuan pertama sampai dengan pertemuan kelima terlihat peningkatan layanan informasi karir dengan media buku bergambar siswa dari setiap pertemuan sampai pada akhirnya pada pertemuan kelima 3 orang siswa berada pada kategori tinggi dan 17 orang siswa berada pada kategori sangat tinggi.

Pada akhir penelitian atau sesudah pemberian perlakuan terhadap 20 orang siswa, ditemukan perbedaan antara sebelum dan sesudah pemberian layanan informasi karir dengan media buku bergambar. Dalam hal ini. Peningkatan skor dari kategori rendah ke kategori tinggi memberikan indikasi bahwa ada efek positif dari pemberian layanan informasi karir dengan media buku bergambar tersebut.

Tingginya pemahaman terhadap studi lanjutan siswa di SMP Negeri 23 Makassar disebabkan pemberian informasi tentang berbagai jurusan apa yang ada di SMA/MAN atau SMK dan setelah lulus SMA/MAN atau SMK bisa lanjut kemana dalam bentuk media buku bergambar.

Siswa di sekolah memahami dunia kerja, karir, dan lingkungannya maka dipandang perlu memberikan informasi tentang jenis-jenis karir, pekerjaan atau jabatan yang tersedia dalam pasaran kerja baik dalam skala lokal maupun nasional sehingga dapat menambah pemahaman karir siswa.

Selanjutnya, Sering dijumpai adanya kebingungan, keragu-raguan dan kesulitan diantara para siswa yang sedang menekuni studinya di pendidikan formal dan akan mempersiapkan dirinya untuk meniti karir di masa-masa mendatang, terutama karena diantara para siswa kurang memahami dirinya, memahami dunia kerja, ambisinya dalam dunia kerja dan peningkatan karirnya.

Pemberian layanan informasi mengenai studi lanjut sudah diberikan tetapi belum maksimal, hal ini dikarenakan Guru BK hanya diberi kesempatan masuk kelas ketika jam pelajaran kosong. Didalam memberikan memberikan informasi Guru BK menggunakan metode ceramah dalam hal ini membuat siswa merasa bosan dan tidak bersemangat untuk mendengarkan informasi studi lanjut. Hal ini mengakibatkan siswa kurang memahami materi studi lanjut.

Menentukan studi lanjut bukanlah hal yang mudah dan tidak asal pilih saja, karena jika salah dalam memilih akan berakibat fatal, untuk itu perlu sekali pembekalan sejak dini mengenai informasi mengenai studi lanjut. Sutikna (1998: 17) mengartikan studi lanjut sebagai "pendidikan sambungan atau lanjutan setelah tamat dari pendidikan yang saat ini ditempuh". Studi lanjut yang dimaksud dalam hal ini adalah pendidikan lanjutan setelah menamatkan SMP dan ingin melanjutkan ke jenjang berikutnya.

Layanan informasi karir dengan media buku bergambar efektif meningkatkan pemahaman terhadap studi lanjutan siswa, ini terjadi karena melalui proses yang panjang dimana siswa diberikan latihan-latihan untuk mengenal sekolah lanjutan setelah tamat SMP nantinya seperti informasi tentang jurusan apa yang ada di SMA/MAN atau SMK dan setelah lulus SMA/MAN atau SMK bisa lanjut kemana.

\section{SIMPULAN DAN SARAN}

Berdasarkan hasil penelitian tentang efektifitas layanan informasi karir dengan media buku bergambar di SMP Negeri 23 Makassar, maka dapat dikemukakan beberapa kesimpulan yaitu: Gambaran pemahaman terhadap studi lanjutan siswa di SMP Negeri 23 Makassar, dari hasil pre-test baik kelompok eksperimen maupun kontrol berada pada kategori rendah. Namun demikian, siswa yang telah diberi layanan informasi media buku bergambar menunjukkan perubahan dari tingkat pemahaman terhadap studi lanjutan siswa dari rendah menjadi kategori tinggi, sedangkan bagi siswa yang tidak diberi layanan informasi media buku bergambar tidak menunjukkan perubahan berarti atau tetap dalam kategori rendah. Ada pengaruh layanan informasi karir dengan media buku bergambar terhadap peningkatkan pemahaman terhadap studi lanjutan siswa di SMP Negeri 23 Makassar.

Disarankan hendaknya konselor sekolah dapat melaksanakan proses tersebut (1) Bagi siswa, dapat membantu dalam proses pemahaman terhadap studi lanjutan siswa, sehingga mampu membuat keputusannya 
sendiri. (2) Kepada rekan-rekan mahasiswa dan peneliti, di prodi jurusan bimbingan konseling, agar dapat mengembangkan media buku bergambar ini dalam mengatasi permasalahanpermasalahan yang berbeda pula dan dalam memanilisir agar dalam kelas bisa diatur bisa kita meminta bantuan kepada guru pembimbing yang ada disekolah.

\section{DAFTAR RUJUKAN}

Gani, R. A. 2012. Bimbingan Karir. Bandung: Angkasa.

Nursalim, Moch dan SA, Suradi. 2002. Layanan Bimbingan dan Konseling. Surabaya: Unipress.

Prayitno dan Erman Amti. 2004. Dasar-dasar Bimbingan dan Konseling. Jakarta: Rineka Cipta.

Riduwan. 2009. Belajar Mudah Penelitian Untuk Guru-Karyawan dan Peneliti Pemula. Bandung: Alfabeta.

Sutikna, Agus. 1998. Bimbingan Karir Untuk SMA. Jakarta: Intan Pariwara.

Wiersma, William. 1995. Research Methods In Education An Introductio Sixth Edition. London: Allyn and Bacon.

Yusuf. 2008. Psikologi Perkembangan Anak dan Remaja. Bandung: Rosdakarya. 